The Catholic University of America, Columbus School of Law

CUA Law Scholarship Repository

\title{
Freedom and Equality in the Religion Clauses
}

John H. Garvey

The Catholic University of America, Columbus School of Law

Follow this and additional works at: https://scholarship.law.edu/scholar

Part of the Constitutional Law Commons, and the Religion Law Commons

\section{Recommended Citation}

John H. Garvey, Freedom and Equality in the Religion Clauses, 1981 SUP. CT. REV. 193.

This Article is brought to you for free and open access by the Faculty Scholarship at CUA Law Scholarship Repository. It has been accepted for inclusion in Scholarly Articles and Other Contributions by an authorized administrator of CUA Law Scholarship Repository. For more information, please contact edinger@law.edu. 


\section{JOHN H. GAR VEY}

\section{FREEDOM AND EQUALITY IN \\ THE RELIGION CLAUSES}

The Supreme Court has been extremely puzzled about how to treat the distribution of public benefits when the pattern of distribution may cause individuals to alter their preferences in making constitutionally protected choices. When dealing with the freedom to choose an abortion, for example, the Court held that the Hyde Amendment was constitutional because the government did not interfere with freedom when all it did was offer money to make the option it preferred (childbirth) more attractive. ${ }^{1}$ In free speech cases, the Court has said that when the government opens up public property or offers financial incentives to speakers it must treat all options equally -it may not favor a particular subject or position. ${ }^{2}$ Last term, in Thomas v. Review Board, ${ }^{3}$ the Court held that when freedom of religion is at stake, the government has an independent obligation to fund the option which the individual finds more attractive. The case directed the state of Indiana to pay unemployment compensation to one who quit his job for religious reasons, even though the state paid nothing to those who quit for other personal reasons. The allocation of public funds has created similar

\footnotetext{
John H. Garvey is Law Alumni Professor of Law, University of Kentucky College of Law.

AUTHOR'S NOTE: I would like to thank Thomas P. Lewis for his careful reading and generous criticism of an earlier draft of this paper.

${ }^{1}$ Harris v. McRae, 448 U.S. 297 (1980). Cf. Maher v. Roe, 432 U.S. 464 (1977).

${ }^{2}$ Carey v. Brown, 447 U.S. 455 (1980); Police Dept. of the City of Chicago v. Mosley, 408 U.S. 92 (1972). Cf. Speiser v. Randall, 357 U.S. 513 (1958).

${ }^{3} 101$ S. Ct. 1425 (1981).

(C) 1982 by The University of Chicago. All rights reserved.

$0-226-46434-2 / 82 / 1981-0025 \$ 01.00$
} 
problems with regard to other constitutional freedoms, such as travel, ${ }^{4}$ voting, ${ }^{5}$ and parental choices about their children's education. ${ }^{6} \mathrm{I}$ think that all these cases present questions of equality rather than freedom, and that the free exercise and abortion decisions err on different sides of the correct principle. The proper approach is to say, as the Court has regarding freedom of speech, that the government need not fund protected choices, but if it does, it must do so in a neutral fashion. If that is correct, then the question Thomas poses is not whether Indiana had prohibited the freedom to exercise religious belief but whether the Court, by awarding benefits, violated the equality principle inherent in the Establishment Clause.

\section{The Thomas CASE}

\section{A. THE FACTS AND PROCEEDINGS BELOW}

Eddie Thomas, a Jehovah's Witness, was hired to work at the Blaw-Knox Foundry and Machinery Company in the roll foundry, which fabricated sheet steel for a variety of uses. After he had worked there about a year, the roll foundry was closed, and he was transferred to a department which made turrets for military tanks. Thomas shortly concluded that his new position required him to work directly in the production of armaments in a way that conflicted with religious principles he found in scripture. An examination of the other departments in the plant convinced him that he would face a similar conflict at any other job Blaw-Knox might offer him, the roll foundry having been closed. He asked to be laid off, was denied, and quit after a few weeks in the turret department. ${ }^{7}$

Thomas then applied for unemployment compensation and stated in his claim that he had voluntarily quit his job because of religious convictions. Under the Indiana Employment Security Act, benefits are denied to "an individual who has voluntarily left

\footnotetext{
${ }^{4}$ Memorial Hospital v. Maricopa County, 415 U.S. 250 (1974); Shapiro v. Thompson, 394 U.S. 618 (1969).

S Buckley v. Valeo, 424 U.S. 1, 94-95 (1976).

${ }^{6}$ Norwood v. Harrison, 413 U.S. 455, 462 (1973).

7 Thomas v. Review Bd., 391 N.E.2d 1127, $1128-29$ (Ind. 1979).
} 
his employment without good cause in connection with the work."8 The phrase "good cause in connection with the work" is understood to mean a provocation attributable to the employer which makes the decision to quit objectively justifiable. ${ }^{9}$ One forced to work under conditions hazardous to his health has good cause to quit: ${ }^{10}$ one who quits because of parental obligations or transportation difficulties does not. ${ }^{11}$ Thomas contended that the responsibility for his termination really lay with Blaw-Knox, since it had closed the roll foundry, into which he had been hired on the recommendation of a fellow church member. He supported that claim by pointing out that his application for employment stated that he was a Jehovah's Witness and that his hobby was reading the Bible. ${ }^{12}$ Both the appeals referee and the Employment Security Review Board rejected his claim. Since the circumstances of Thomas's hiring did not show that he had imposed contractual conditions on his employment, Blaw-Knox was entitled to require him to work anywhere in the plant. ${ }^{13}$ The only relevant cause of Thomas's decision to quit was his personal religious objection to working on weapons.

Even if Thomas could not squeeze within the language of the statute, he might win by showing that the interpretation of the "good cause" provision was unconstitutional. Sherbert $v$. Verner ${ }^{14}$ offered considerable help on that score. State law there had provided that one already unemployed who refused without good cause to accept a job could not get unemployment compensation. ${ }^{15}$ The Supreme Court had held that it was unconstitutional to use that provision to deny benefits to a Seventh Day Adventist who refused to accept Saturday work for religious reasons. Such a burden on free exercise could only be justified by a compelling state

\footnotetext{
${ }^{8}$ Indiana Code \& 22-4-15-] (Burns Code Ed. 1974, Supp. 1978).

${ }^{9}$ See, e.g., Gray v. Dobbs House, Inc., 357 N.E.2d 900, 903-05 (Ind. Ct. App. 1976); Lewis v. Review Board, 282 N.E.2d 876, 882-83 (Ind. Ct. App. 1972); Geckler v. Review Board, 193 N.E.2d 357, 359 (Ind. 1963).

${ }^{10}$ Evans v. Enoco Collieries, 96 N.E.2d 674 (Ind. App. 1951).

11 Gray v. Dobbs House, Inc., note 9 supra.

12 Thomas v. Review Bd., 381 N.E.2d 888, 889 (Ind. Ct. App. 1978).

${ }^{13}$ Id. at 890 . It would be hard to blame the company for not foreseeing the turn Thomas's conscience would take. His friend, a Jehovah's Witness, who had helped him get the job, had no scruples about working in the turret department. Ibid.
}

14374 U.S. 398 (1963).

15 S.C. Code $\$ 68-114(3)$ (a), quoted in 374 U.S. at 400 n.3. 
interest, ${ }^{16}$ and the review board in Thomas had conceded that it could not meet that test. ${ }^{17}$ The Indiana Court of Appeals found the analogy to Sberbert persuasive and overturned the review board's decision. ${ }^{18}$

The Indiana Supreme Court reversed and reinstated the board's decision. It found Sherbert inapplicable because Thomas's decision to quit was a "personal philosophical choice rather than a religious choice." ${ }^{19}$ According to the court, the line between fabricating steel in the roll foundry and using the fabricated steel to make turrets was a rather fine one, and Thomas had neither articulated the religious basis for the distinction nor shown that other members of his congregation subscribed to it. ${ }^{20}$ The court also held that payment of benefits to Thomas would violate the Establishment Clause because the purpose and effect of such action would be protection of religious belief. ${ }^{21}$

\section{B. THE SUPREME COURT'S OPINION}

The Chief Justice began his opinion for the Court by saying that Thomas's reasons for quitting were unquestionably religious in the sense required for protection by the free exercise clause. It did not matter that Thomas found a difference of principle between two different stages in the production of weapons. "[R]eligious beliefs need not be acceptable, logical, consistent, or comprehensible to others in order to merit First Amendment protection."22 Nor was it significant that his interpretation of scripture was not shared by other members of his faith. The guarantee of free exercise is not limited to doctrines that command universal assent within a sect; and where there is disagreement, courts are not competent to say who is right.

Up to that point, the Court was on safe ground. The trouble started when it addressed the second issue: whether the mere denial of unemployment compensation to one who quit his job for reli-

\footnotetext{
16374 U.S. at 406.

17381 N.E. $2 d$ at $890-93$.

${ }^{18} \mathrm{Id}$. at 888.

19391 N.E.2d at 1131.

${ }^{20}$ Id. at $1131-33$.

21 Id. at 1134.

$22101 \mathrm{~S}$. Ct. at 1430.
} 
gious reasons counted as a prohibition of freedom of religion. The Chief Justice began with the unimpeachable observation that "the Indiana law does not compel a violation of conscience." ${ }^{23}$ But having said that, he went on to find $\mathrm{a}^{24}$

coercive impact on Thomas ... indistinguishable from Sberbert. ... Where the state conditions receipt of an important benefit upon conduct proscribed by a religious faith, or where it denies such a benefit because of conduct mandated by religious belief, thereby putting substantial pressure on an adherent to modify his behavior and to violate his beliefs, a burden upon religion exists. While the compulsion may be indirect, the infringement upon free exercise is nonetheless substantial.

He even quoted the parallel that Sherbert found most apt to describe the nature of the coercion: ${ }^{25}$

"Governmental imposition of such a choice puts the same kind of burden upon the free exercise of religion as would a fine imposed against [her] for her Saturday worship."

The outcome of the case followed inexorably, once that problematic assumption was made. If the mere failure to pay benefits was "coercive," an "indirect compulsion" indistinguishable from a fine, then the state would need compelling reasons to justify such a severe restriction of free exercise. The board had offered no proof that the number of people who voluntarily quit jobs for religious reasons would be sufficiently great to imperil the solvency of the state's unemployment fund. Nor was there any showing that the number would be large enough to prompt employers to probe the religious beliefs of their job applicants and hire only those whose principles were compatible with the nature of the employer's business.

Having concluded that Indiana's law restricted religious freedom, the Court faced a third issue: whether paying benefits to Thomas while denying them to those who quit jobs for personal but nonreligious reasons would foster religion in violation of the Establishment Clause. That contention, too, had been advanced and rejected in Sherbert $v$. Verner, and the majority found no reason to disturb its earlier holding that an accommodation of religious free-

23 Id. at 1431 .

24 Id. at 1432.

${ }^{25}$ Id. at 1431, quoting Sherbert v. Verner, 374 U.S. at 404. 
dom did not amount to an impermissible involvement of religious with secular institutions. ${ }^{26}$

Justice Rehnquist dissented. He concluded that the Court's broad reading of the Free Exercise Clause created an irreconcilable conflict with the Establishment Clause. If Sherbert and Tbomas stand for the principle that the government cannot put pressure on religious belief by withholding monetary benefits, it might equally be argued that "a State may not deny reimbursement to students who choose for religious reasons to attend parochial schools." ${ }^{27}$ On the other hand, if we adhere to the three-part test currently used to enforce the Establishment Clause, Indiana would be constitutionally forbidden to legislate the result that Sherbert and Tbomas require. In the first place, a law allowing benefits to those who quit jobs for religious reasons (while denying them to those who quit for other personal reasons) would serve a religious, not a secular, purpose. Second, the primary effect of such a law would be to advance religion by funding the exercise of religious choices. Third, the law would invite entanglement, because it would require the state to investigate the religious nature and sincerity of a claimant's belief.

\section{The Limits of Freedom: Restriction of Choice}

The basic mistake that the Court made in both Thomas and Sherbert was to assume that the failure to pay unemployment compensation burdened the free exercise of religion. In fact, a proper understanding of the freedom protected by the Constitution shows that neither case involved any restriction on liberty at all.

\section{A. A COMMON SENSE LOOK AT FREEDOM, CHOICE, AND MOTIVE}

What distinguishes constitutional freedoms (such as speech and religion) from other constitutional rights (such as the right to a jury trial and the protection against cruel and unusual punishment) is that freedoms give protection to choices. Freedom of speech protects the choice to praise the president, the choice to condemn him, and the choice to keep silent. The Seventh Amendment, in contrast, does not protect the choice to try one's case without a jury.

${ }^{26} 101 \mathrm{~S}$. Ct. at 1433. Justice Blackmun concurred in the opinion on the first two points and in the result on the third-the establishment question. Ibid.

27 Id. at 1435 n. 2 (Rehnquist, J., dissenting). 
The government may act in a number of ways to affect the outcome of the process of choice. ${ }^{28}$ (1) It might compel an individual to choose the option that the government prefers, under the threat of fine or imprisonment for noncompliance. ${ }^{29}$ (2) It might forbid or deter choice of the option that the individual prefers, either by making that option a criminal offense or by increasing the cost of the preferred option without making it illegal. ${ }^{30}$ (3) The government might try to induce (rather than compel) choice of the option that it prefers by offering a monetary reward or similar bait to those who comply. ${ }^{31}$ (4) Finally, the state might discourage (rather than forbid or deter) choice of the option that the individual prefers by withholding monetary or other benefits that the individual desires to receive. The last was the type of state action involved in Sherbert and Thomas. ${ }^{32}$

${ }^{28}$ In addition to the four examples which are discussed in text, the government may also, though it seldom does, simply prevent exercise of a preferred choice by making it impossible. One example might be locking the individual up in advance of his action. A second example outside the free exercise context might be laws which prevent a candidate's name from appearing on the ballot, thereby preventing the voter's freedom to choose that individual as his representative and the candidate's freedom to run for office. See text at notes 46-48 infra. In these cases the individual's action (going to jail, staying off the ballot) is not voluntary, much less free, see text at note \& note 33 infra, because he could not choose to do otherwise.

${ }^{29}$ Wisconsin v. Yoder, 406 U.S. 205 (1972), is an example. The state of Wisconsin required parents to send their children to public or private school until they reached age sixteen. Violation was punished by fine or imprisonment. High school attendance violated the tenets of the Old Order Amish religion. See also West Virginia State Board of Education v. Barnette, 319 U.S. 624 (1943).

${ }^{30}$ An example of a law forbidding a choice preferred by the individual is the federal bigamy statute upheld in Reynolds v. United States, 98 U.S. 145 (1878). The law made bigamy a criminal offense; the defendant, a Mormon, was required by his religion to practice polygamy. An example of a law deterring a preferred choice without making it illegal is the license tax invalidated in Murdock v. Pennsylvania, 319 U.S. 105 (1943). The ordinance there required religious colporteurs to pay a flat fee for doing what they thought was a religious duty. Cf. Braunfeld v. Brown, 366 U.S. 599 (1961).

The essential difference between case 1 (compelling) and case 2 (forbidding or deterring) is that in the former the individual must undertake the specific activity favored by the government (go to school, salute the flag) or be subjected to sanctions. In the latter case the individual is free to pursue any option except the one disfavored by the government. Reynolds was free, as far as the government was concerned, to remain unmarried or to get married only once. Murdock was free in the same sense to distribute tracts free of charge, to convey his message orally, and so on.

${ }^{31}$ The Hyde Amendment is a good example. See note 1 supra. A challenge to it on free exercise grounds was dismissed in Harris v. McRae for lack of standing, note I supra, at $320-21$.

32 The difference between case 3 (the Hyde Amendment) and case 4 (Thomas) is that a pregnant woman can, by the choice she makes, control whether she will get benefits or not. Thomas, on the other hand, had no choice open to him which would produce governmental benefits. He could only elect between keeping his job (and drawing wages paid by Blaw- 
In cases 1 and 2, the individual will do what the government wants him to voluntarily but not freely. His action is voluntary in the sense that he chooses to do it; it is unfree in the sense that his choice results from a motive that he wishes were not affecting him. Suppose it is a religious holy day and I want to go to church. ${ }^{33}$ I may nevertheless choose not to if (1) the state will penalize me for skipping school; or if (2) the state will penalize me for going to church, though I may do whatever else I want. In either case, I could do otherwise, if I chose to. My decision not to go to church is not a reflex action such as a knee jerk, or a simply physical reaction such as being pushed into someone in front of me, but one I have willed to do after weighing my distaste for sanctions against my desire to conform to my religious obligations. In that sense, my action is voluntary. But it is unfree because the state has influenced the outcome of my choice of actions by supplying me with a motive (fear of sanctions) which I would not choose.

From a common sense way of speaking, however, in cases 3 and 4 the individual acts both voluntarily and freely. In both cases, his action results from choice, so it is voluntary. In both cases, his action is also free, because it either proceeds from a motive that he was happy to have the state supply (case 3), or it proceeds from motives that are unaffected by state action (case 4). ${ }^{34}$ Suppose that I want to go to the movies this afternoon. I may choose not to go because (3) you offer me a free ticket to the Cubs game, or because (4) I have used up all my paid vacation and would have to take the

Knox) and quitting (without compensation of any kind). To use the standard metaphor, the government influences the pregnant woman's choice by offering her a carrot; it influences Thomas's choice by failing to offer him a carrot.

${ }^{33}$ My use of the word "voluntary" follows MOORE, ETHICs 12-16 (1912). In using the word "motive" I refer to the individual's disposition or desire to achieve or avoid a certain end. The desire to acquire money and the fear of going to jail are two types of motives, which the state may cause to arise in an individual by inducement or threat. Though motives may determine one's choices, so that he generally does what he wants to do, a motive itself may be one he does not desire. My use of "motive" also parallels Plamenatz's usage in his CONSENT, FREEdOM AND PoldTICAL OBLigation 111-13,118, 122 (2d ed. 1968). With this stipulation I hope I can avoid the controversy about the respective meanings of "reason," "motive," and "intention." For an introduction to the literature on that subject, see RAZ, PraCTiCal REASONING (1978); H. MORRIS, FREledOM AND ReSPONSIBILITY 158-230 (1961).

${ }^{34}$ Cf. Bayles, A Concept of Coercion, XIV Nomos: CoERcion 16 (1972): Gert, Coercion and Freedom, id. at 30; PlamenaTZ, note 33 supra, at 122 . For a contrary view that enticement may be coercive, and hence restrict freedom, see Held, Coercion and Coercive Offers, XIV Nomos: Coercion at 49. The fault of Held's analysis is that she relies on examples which may be explained more appropriately as denials of equality than as limitations of freedom. Id. at 56-57. See text at notes 53-66 infra. 
afternoon off without pay. In case 3, the motive that determines my choice not to go to the movies is one that I want to have affecting me. I value a movie for which I have to pay at less than I value a free baseball game, and if it were in my control I would choose to have you offer me a ticket to the game. I may be unhappy that you did not also offer me a free movie pass (since I might then have gone to the movies rather than to the game), but I undoubtedly see myself as, if anything, more free than I would have been if you had done nothing. In case 4 , my choice would not be affected by the fact that other employees still had vacation coming to them and could take the afternoon off with pay. The question for me would still be whether I valued a movie more or less than I valued an afternoon's wages. I might be unhappy that I too could not get paid while going to the matinee, but the reason I do not have that option is that I have just spent a week at the beach.

What is true of that innocuous illustration is equally true if we adapt it to religious choices. Thomas is no less free if he wants to go to church (instead of the movies) and the government offers him $\$ 100$ to do something else. He is also no less free to do what his conscience directs if he wants to quit and others who have "good cause" to quit get unemployment benefits (instead of paid vacation). $\mathrm{He}$ is free in the former situation because a bounty of $\$ 100$ - unlike a tax, a fine, or a jail term-provides a motive he wants to have affecting him. His choices are enhanced, rather than restricted, by the government's action. He is free in the latter situation because his choice to exercise his belief is unaffected by the fact that the state pays benefits to others who quit for good cause. The government has neither restricted his choices nor supplied him with any motive that affects his decision.

There are several points about the problem in Thomas that seem to distinguish it from the moviegoer in case 4 . One obvious difference is Thomas's need for unemployment benefits. It is certainly easier to take off an afternoon without pay than it is to quit one's job with no assurance of another source of income. And as Franklin D. Roosevelt once said, "Necessitous men are not free men." 35 But that suggests that Indiana would violate Thomas's freedom of religion if it had no unemployment compensation system whatsoever-or, to turn it around, that the state must act to make

${ }^{35}$ Message to Congress, 90 Cong. Rec. 57 (1944). 
people free by assuring the satisfaction of their basic needs. That suggestion, for all its humanitarian appeal, is one I am sure the Court did not intend to make.

A second argument-one which makes Thomas look more like case 2 (in which the state increases the cost of the individual's preferred option)-might be that Thomas was more entitled than was the hypothetical moviegoer to income while he was not working. As one's entitlement becomes more secure, the state's refusal to pay looks more like a debit than a lost opportunity. And one who holds a job against his religious principles then is not free in the sense that his action is determined, as in case 2 , by a motive that he does not desire: loss of "his" benefits if he quits. The Court would then be correct in saying that "Governmental imposition of such a choice puts the same kind of burden upon the free exercise of religion as would a fine imposed aginst appellant. . . ."36

Of course, in a positivistic sense, Thomas had no more claim to benefits than I would have to an extra vacation day to attend the movies. Had he asked a good lawyer before quitting whether his reason satisfied Indiana's "good cause" requirement, he would have been told no. On the other hand, Blaw-Knox's contribution to the unemployment fund was made possible by the value of Thomas's services and might in other circumstances have passed to him in the form of higher pay and resultant higher private savings to sustain himself after he quit. Thus, it could be argued that by operating its unemployment compensation program, Indiana took away from Thomas money that he needed to exercise his religious belief. Now that he has quit, Indiana has to give it back.

That sort of argument will not work for a number of reasons. One is that it rests on an inaccurate factual assumption. Indiana's unemployment compensation scheme was an insurance program, and the size of the premiums paid in on Thomas's behalf might be considerably smaller than the amount of benefits he was claiming. ${ }^{37}$ A second reason is that the argument rests on assumptions of causation that in many cases will prove unjustified: if Indiana had not enacted an unemployment insurance program, Blaw-Knox may

\footnotetext{
${ }^{36} 101$ S. Ct. at 1431 , quoting Sherbert v. Verner, note 14 supra, at 398, 404.

${ }^{37}$ Cf. Fleming v. Nestor, 363 U.S. 603, 610 (1960). ("To engraft upon the Social Security system a concept of 'accrued property rights' would deprive it of the flexibility and boldness in adjustment to ever-changing conditions which it demands.")
} 
have kept the extra money rather than passed it on, or the job market may have been so changed by the lack of employment security that Thomas would have gone to work somewhere else in the first place. In case 2, the state's action is keyed to the protected choice; an effect on motives is guaranteed by the way the law is designed to operate. The state says, for example, that if you want to ring doorbells to sell religious literature (or pots and pans), you must pay a fee for a license. ${ }^{38}$ In Thomas, the state's act of collecting unemployment insurance may not play any role at all in Thomas's later choice about quitting.

\section{B. A CONSTITUTIONAL PERSPECTIVE ON FREEDOM, CHOICE, AND MOTIVE}

If what the preceding section says were to be reflected in constitutional law, one would be left with the uneasy feeling that the state could rid itself of Hare Krishnas, Moonies, and, for that matter, Jehovah's Witnesses by an appropriately cunning fiscal policy. In this section, I would like to make two points: first, that the common sense view of freedom (choice proceeding from a motive which either is actively desired or is unaffected by state action) finds support in cases defining constitutional freedoms; and second, that cases that seem to reject that view in fact point toward a different limit on the government's power to buy out Jehovah's Witnesses-the principle of equality.

Support for the common sense view of freedom is most frequently found in cases, like case 3 above, in which the government attempts to induce choice of the option that it prefers by offering a monetary reward or similar bait to those who comply. Funding for childbirth, but not for abortion, is the best current example. Like the freedoms of speech and religion, the aspect of due-process liberty recognized in Roe $v$. Wade ${ }^{39}$ offers protection for choice-in this case the choice whether to bear a child. Yet in Harris v. McRae, the Supreme Court said that that freedom of choice was not impinged on by a Medicaid system which paid for childbirth but not abortion, because a woman's choice was not restricted. ${ }^{40}$ The foun-

\footnotetext{
${ }^{38}$ Murdock v. Pennsylvania, note 30 supra, at 105.

${ }^{39} 410$ U.S. 113 (1973).

${ }^{40} 448$ U.S. at $316-18$.
} 
dation for that conclusion was laid three years earlier in Maber $v$. Roe, which found ${ }^{41}$

a basic difference between direct state interference with a protected activity and state encouragement of an alternative activity consonant with legislative policy. Constitutional concerns are greatest when the State attempts to impose its will by force of law; the State's power to encourage actions deemed to be in the public interest is necessarily far broader.

That difference between case 1 (compelling) or case 2 (forbidding), on the one hand, and case 3 (inducing), on the other, exists because in the case of inducement the woman acts from a motive she desires. The state has influenced the woman's decision by "ma[king] childbirth a more attractive alternative, . . . but it has imposed no restriction on access to abortions that was not already there." 42 The pregnant woman might be happier if the state also offered to fund abortions, but "it simply does not follow that a woman's freedom of choice carries with it a constitutional entitlement to the financial resources to avail herself of the full range of protected choices." 43

The common sense view of freedom is also reflected in cases, like case 4 above, in which the state discourages choice of the option the individual prefers by withholding benefits the individual desires to receive. Consider the challenge to public financing of presidential election campaigns in Buckley $v$. Valeo. ${ }^{44}$ The plaintiffs complained that Subtitle $\mathrm{H}$ of the Internal Revenue Code, ${ }^{45}$ by restricting the public subsidy available to minor and new parties in primary and general election campaigns, infringed various freedoms that have

41432 U.S. $464,475-76$ (1977) (footnote omitted).

${ }^{42} \mathrm{Id}$. at 474.

${ }^{43} \mathrm{McRae}$, note 1 supra, at 316 . The Court reached a similar conclusion in Norwood v. Harrison, note 6 supra, at 455 , regarding another aspect of due process liberty. Pierce $v$. Society of Sisters, 268 U.S. 510 (1925), held that the Fourteenth Amendment protected a parent's freedom to choose private, rather than public, education for his child. Obviously the state makes choice of a public education more attractive by paying the bill. The appellees in Norwood argued that such an inducement violated the Equal Protection Clause by discriminating against those who exercised the freedom recognized in Pierce, and that Mississippi was constitutionally required to provide free textbooks to private school students. The Court said, "It is one thing to say that a State may not prohibit the maintenance of private schools and quite another to say that such schools must, as a matter of equal protection, receive state aid." Note 6 supra, at 462.

${ }^{44} 424$ U.S. 1 (1976).

4526 U.S.C. $\$ \S 9001-12,9031-42$ (1970, Supp. IV). Section 6096 provided for designation of income tax payments to the Presidential Election Campaign Fund. 
been secured in voting cases under the Equal Protection Clause: the voter's freedom to choose a representative of his interests, the voter's freedom of political association, ${ }^{46}$ and the candidate's freedom to run for office. ${ }^{47}$ The Supreme Court held that there was a difference between withholding benefits (case 4), on the one hand, and laws that actually prevented a candidate's name from appearing on the ballot. ${ }^{48}$

[The latter are] direct burdens not only on the candidate's ability to run for office but also on the voter's ability to voice preferences regarding representative government and contemporary issues. In contrast, the denial of public financing to some Presidential candidates is not restrictive of voters' rights and less restrictive of candidates'. Subtitle $\mathrm{H}$ does not prevent any candidate from getting on the ballot or any voter from casting a vote for the candidate of his choice; the inability, if any, of minorparty candidates to wage effective campaigns will derive not from lack of public funding but from their inability to raise private contributions.

Such cases suggest that the common sense view of what counts as a restriction on freedom is one the Supreme Court has adopted when enforcing constitutional liberties. ${ }^{49}$ There are, though, even more decisions that seem to point in the opposite direction-to say that the distribution of public benefits either to induce or to discourage a particular result of a protected choice counts as an interference with constitutional freedom. Let me refer to three groups of such cases, all like Thomas (and case 4 above), in which the state has

${ }^{46}$ See Williams v. Rhodes, 393 U.S. 23 (1968); Storer v. Brown, 4] 5 U.S. 724, 729 (1974); Lubin v. Panish, 415 U.S. 709, 716 (1974); Developments in tbe Law, Elections, 88 HARV. L. REV. 1111, 1134-36 (1975). The right to vote itself, though not explicitly denominated a "freedom" in the Constitution, offers protection for choice. A voter may not only vote for the candidate he chooses but is free (unlike voters in Belgium, for example) not to vote at all.

${ }^{47}$ Buckley, note 5 supra, at 94 . The candidate's interest is not of a stature sufficient to provoke a strict standard of review. Bullock v. Carter, 405 U.S. 134, 142-43 (1972).

48424 U.S. at 94-95 (footnote omitted). Keeping a candidate's name off the ballot is a case of preventing, see note 28 supra, rather than compelling (case 1) or forbidding (case 2). It is a more drastic interference with freedom than either of those cases since the individual's action is involuntary.

${ }^{40}$ One possible difference between Tbomas and cases like Harris v. McRae and Buckley might be that in Tbomas the choice favored by the petitioner is seen as a matter of duty, whereas the choice to have an abortion, to run for office, and so on are not usually viewed in that light. There surely is something morally repugnant about intentionally tempting someone to violate or discouraging someone from following a moral or religious obligation. $C f$. Bayles, Limits to a Rigbt to Procteate, in HAving CHILDREN 13, 15 (O'Neill \& Ruddick eds. 1979). 
discouraged choice of the option the individual prefers by withholding public benefits the individual desires. First are the so-called right-to-travel cases, which in fact involve the freedom to migrate from one state to another. ${ }^{50}$ The Supreme Court has blocked state efforts to discourage migration by withholding such public benefits as welfare ${ }^{51}$ and medical care. ${ }^{52}$ Second is a cluster of cases involving government employees, in which the state affects choices concerning free speech, association, or even free exercise ${ }^{53}$ by refusing to put on the public payroll people who will not take a loyalty oath ${ }^{54}$ or subscribe to some other orthodoxy. ${ }^{55}$ In all of the cases referred to, the Court has invalidated the conditions on public employment. Third are the public forum cases, in which the Court has forbidden states to fiddle with religion ${ }^{56}$ or speech $^{57}$ by closing the streets, parks, and so on to advocates of disfavored positions or subjects.

I want to suggest that, far from undermining the concept of freedom for which $I$ have been arguing, these cases show that the manipulation of public benefits produces problems of equality, not freedom. In the first place, each of the three groups of cases (travel, conditions on employment, public forum) resolves an issue that

${ }^{50}$ Memorial Hospital v. Maricopa County, note 4 supra, at 250, 254; Shapiro v. Thompson, note 4 supra, at 618, 629, 630.

51 Shapiro v. Thomson, note 4 supra. Cf. Vlandis v. Kline, 412 U.S. 441 (1973).

52 Memorial Hospital v. Maricopa County, note 4 supra.

${ }^{53}$ Torcaso v. Watkins, 367 U.S. 488 (1961). Cf. McDaniel v. Paty, 435 U.S. 618 (1978).

54 Whitehill v. Elkins, 389 U.S. 54 (1967); Keyishian v. Board of Regents, 385 U.S. 589 (1967); Elfbrandt v. Russell, 384 U.S. 11 (1966); Baggett v. Bullitt, 377 U.S. 360 (1964); Cramp v. Board of Public Instruction, 368 U.S. 278 (1961).

55 Perry v. Sindermann, 408 U.S. 593, 597 (1972); Pickering v. Board of Education, 391 U.S. 563, 568 (1968).

${ }^{56}$ Niemotko v. Maryland, 340 U.S. 268 (1951). Cf. Fowler v. Rhode Island, 345 U.S. 67 (1953); Kunz v. New York, 340 U.S. 290 (1951). Last term, in Heffron v. International Society for Krishna Consciousness, 101 S. Ct. 2559 (1981), the Court upheld a time, place, and manner regulation of religious solicitation at the Minnesota state fair, relying heavily on the "nondiscriminatory" nature of the rule. See id. at 2562, 2564.

57 Shuttlesworth v. City of Birmingham, 394 U.S. 147 (1969); Cox v. Louisiana, 379 U.S. 536 (1965); Edwards v. South Carolina, 372 U.S. 229 (1963).

If there is such a thing as an absolute right to some minimum access to the public forum, these cases resemble case 2, text at note 30 supra, rather than case 4-the state does not simply withhold something the individual desires but deprives him of something he has. To date, the Supreme Court has kept its own counsel about the degree to which access is unconditionally guaranteed. See Carey v. Brown, note 2 supra, at 455, 459 n.2 (1980); Cox v. Louisiana, note 57 supra, at 555. Cf. United States Postal Service v. Council of Greenburgh Civic Associations, 101 St. Ct. 2676, 2683-87 (1981). 
does not fit the traditional legal (and common sense) view of freedom. The roots of the freedom to migrate are found in older cases outlawing taxes and criminal penalties (case 2) imposed to inhibit interstate travel. ${ }^{58}$ But, as Justice Rehnquist pointed out, a durational residence requirement ${ }^{59}$

raises no comparable barrier. Admittedly, some indigent persons desiring to reside in Arizona may choose to weigh the possible detriment of providing their own nonemergency health care during the first year of their residence against the total benefits to be gained from continuing location within the State, but their mere entry into the State does not invoke criminal penalties. To the contrary, indigents are free to live within the State. . . .

Similarly, the Court for a long time resolved government employee cases by saying that imposing conditions on employment did not interfere with constitutional freedoms. In Justice Holmes's epigram: ${ }^{60}$

The petitioner may have a constitutional right to talk politics, but he has no constitutional right to be a policeman. There are few employments for hire in which the servant does not agree to suspend his constitutional rights of free speech as well as of idleness by the implied terms of his contract. The servant cannot complain, as he takes the employment on the terms which are offered him.

Holmes resolved the public forum cases in the same way, upholding the conviction of a preacher who spoke on the Boston Common without getting a permit from the mayor: ${ }^{61}$

\footnotetext{
${ }^{58}$ See Crandall v. Nevada, 73 U.S. (6 Wall.) 35 (1868); Edwards v. California, 314 U.S. 160 (1941).

${ }^{59}$ Memorial Hospital v. Maricopa County, note 4 supra, at 250, 283 (Rehnquist, J., dissenting).

${ }^{60}$ McAuliffe v. Mayor of New Bedford, 155 Mass. 216, 220, 29 N.E. 517, 517-18 (1892). For later adoptions of the position, see Adler v. Board of Education, 342 U.S. 485, 492 (1952) ("If they do not choose to work on such terms, they are at liberty to retain their beliefs and associations and go elsewhere. Has the State thus deprived them of any right to free speech or assembly? We think not."); Bailey v. Richardson, 182 F.2d 46, 59 (D.C. Cir. 1950), aff'd by an equally divided Court, 341 U.S. 918 (1951) ("The First Amendment guarantees free speech and assembly, but it does not guarantee Government employ.").

${ }^{61}$ Commonwealth v. Davis, 162 Mass. $510,511,39$ N.E. 113 , 113 (1895), aff'd, 167 U.S. 43 (1897). Cf. U.S. Postal Service v. Council of Greenburgh Civic Associations, note 57 supra, at 2676,2685 ("The State, no less than a private owner of property, has power to preserve the property under its control for the use to which it is lawfully dedicated.") (quoting Adderly v. Florida, 385 U.S. 39, 47 [1966]).
} 
For the Legislature absolutely or conditionally to forbid public speaking in a highway or public park is no more an infringement of the rights of a member of the public than for the owner of a private house to forbid it in his house.

In the second place, the Court's recent opinions condemning the manipulation of public benefits make clear that the evil of the practice is not that it restricts freedom but that it constitutes a denial of equal protection. That conclusion is most evident in the right-totravel cases, in which the basis for decision was the Equal Protection Clause. The principle at stake was nondiscrimination: "Ye shall have one manner of law, as well for the stranger, as for one of your own country." 62 The same is true of the public forum cases, where the Court has recently made explicit what was implicit from the beginning: that "under the Equal Protection Clause, not to mention the First Amendment itself, government may not grant the use of a forum to people whose views it finds acceptable, but deny use to those wishing to express less favored or more controversial views."63 Even before that doctrinal shift, it was well understood that the vice of vagueness in a permit system was the invitation it offered for discriminatory enforcement. ${ }^{64}$ One finds less conscious recognition that the equality principle is at work in the government employment cases, although there are clear signals. ${ }^{65}$ Just as revealing is the frequent reliance here, as in the public forum cases, on

${ }_{62}$ Memorial Hospital, note 4 supra, at 261 (quoting Lev. 24:22); Shapiro, note 4 supra, at 627 (the statute "creates a classification which constitutes an invidious discrimination denying them equal protection of the laws").

${ }^{63}$ Police Department of Chicago v. Mosley, note 2 supra, at 92, 96; Carey v. Brown, note 2 supra, at 455 . Cf. Cox v. Lousiana, note 57 supra, at 557-58 (opinion of the Court), 581 (Black, J., concurring); Fowler v. Rhode Island, note 56 supra, at 67, 70 (Frankfurter, J., concurring); Niemotko v. Maryland, note 56 supra, at 268, 272 (opinion of the Court), 284 (Frankfurter, J., concurring).

${ }^{64}$ Shuttlesworth v. City of Birmingham, note 57 supra at 153; Cox v. Louisiana, note 57 supra, at 557-58; Edwards v. South Carolina, note 57 supra, at 236-37; Kunz v. New York, note 56 supra, at 293. Cf. Heffron v. International Society for Krishna Consciousness, note 56 supra, at 2564 ("Nor does Rule 6.05 suffer from the more covert forms of discrimination that may result when arbitrary discretion is vested in some government authority.").

${ }^{65}$ Cramp v. Board of Public Instruction, note 54 supra, at 288 ("exclusion . . . is patently . . . discriminatory"); Torcaso v. Watkins, 367 U.S. at 492-94 (Establishment Clause); Wieman v. Updegraff, 344 U.S., 183, 191-92 (1952) ("Congress could not 'enact a regulation providing that no Republican, Jew or Negro shall be appointed to federal office, or that no federal employee shall attend Mass or take any active part in missionary work.' ... We need not pause to consider whether an abstract right to public employment exists. It is sufficient to say that constitutional protection does extend to the public servant whose exclusion pursuant to a statute is patently arbitrary or discriminatory."). 
the doctrines of vagueness and overbreadth. ${ }^{66}$ Once again, the concern over such defects is prompted by the opportunity they provide for discriminatory enforcement-the appropriate sin for statutes nearly always aimed at political minorities.

\section{Equality, Affirmative Action, AND the Establishment Clause}

I have argued in Section II that when the government influences constitutionally protected choices by the way it distributes benefits, the problem is one of equality, not freedom. ${ }^{67}$ Taking that perspective on the Thomas case, obviously I suggest a different outcome: Jehovah's Witnesses were treated no differently under Indiana's scheme than were any other employees who voluntarily quit, so Thomas had no greater claim to unemployment compensation than did anyone else who quit for personal reasons. Not only did the case involve no interference with freedom, but also there was no issue of inequality that would justify judicial intervention.

In fact, by deciding Thomas as it did, the Court engaged in a kind of "affirmative action" which may have violated the brand of equality demanded by the Establishment Clause. ${ }^{68} \mathrm{I}$ would like to

${ }^{68}$ Whitehill v. Elkins, note 54 supra, at 62 ("overbreadth ... makes possible oppressive or capricious application"); Keyishian v. Board of Regents, note 54 supra, at 597-604 (vagueness), 609 (overbreadth); Baggett v. Bullitt, note 54 supra, at 369-74 (vagueness); Cramp v. Board of Public Instruction, note 54 supra, at 286-87.

${ }^{67}$ In concluding as I do that the public forum and public employment eases present problems of equality rather than freedom, I do not mean to suggest that they can be resolved by resort to the Equal Protection Clause alone. If we had no First Amendment, the level of scrutiny that would be given classifications disfavoring some speakers would approximate that given classifications disfavoring some recipients of AFDC benefits. See Dandridge v. Williams, 397 U.S. 47I, 484-85 (1970). My point is, rather, that the Court has felt compelled to talk in terms of equality, and indeed to invoke the Equal Protection Clause explicitly, because its consistent understanding of the term "freedom" in the First Amendment (choice proceeding from a motive that is not undesired) does not provide sufficient protection for the values it sees underlying individual and political expression. "Freedom" so defined would allow the government to buy unanimous support for orthodox opinions despite the obviously unhealthy social consequences of such a program. See text at notes 86-88 infra.

${ }^{6 B}$ In referring throughout this section and Sec. IV to the "neutrality" (or "equality") principle, I do not wish to be understood as suggesting that neutrality is an adequate description of the jurisprudence that the Supreme Court has adopted in Establishment Clause cases. I make clear (e.g., text at notes 99,113 infra) that it is not, though the state of the law might be considerably improved if it were. It is enough for my purposes that neutrality is a baseline principle which the Court has consistently reaffirmed. Roemer v. Maryland Public Works Board, 426 U.S. 736, 746-47 (1976) (opinion of Blackmun, J.); Committee for Public Education \& Religious Liberty v. Nyquist, 413 U.S. 756, 788 (1973); Tilton v. Richardson, 403 U.S. 672, 677 (1971) (opinion of Burger, C. J.); Walz v. Tax Commission, 397 U.S. 664, 
explore that question here by looking at parallel types of affirmative action that the Court has approved. One is benign racial classification, a phenomenon to which Thomas bears obvious similarities, for not only there, but in most recent cases, the Free Exercise Clause "has functioned primarily to protect what must be counted as discrete and insular minorities, such as the Amish, Seventh Day Adventists, and Jehovah's Witnesses."69 The other is government sponsorship of speech, a kind of "affirmative action" which the Court has occasionally countenanced despite the general principle of free-speech neutrality. That, too, has a family resemblance to the unique support the Court gave religious objections in Thomas despite the general neutrality principle of the Establishment Clause.

\section{A. BENIGN DISCRIMINATION}

In one way, the affirmative action that the Court took on behalf of religious employees in Thomas is more radical than the benign discrimination at stake in Bakke ${ }^{70}$ and Fullilove. ${ }^{71}$ Thomas does not simply say, as those cases did, that government may act to aid a particular disadvantaged group; it says instead that government must afford a special advantage to religious voluntary quitters. Such mandatory affirmative action makes sense if withholding benefits actually restricts free exercise, ${ }^{72}$ but as I assert in Section II, it does not. If Indiana's law did not violate anyone's constitutional rights, the decision about affirmative aid to religious minorities, just as the decision about affirmative action on behalf of racial minorities, should, as an institutional matter, be left to the discretion of the legislature. That was the solution preferred by Justice Rehnquist in

669 (1970); Epperson v. Arkansas, 393 U.S. 97, 103-04 (1968); Abington School Dist. v. Schempp, 374 U.S. 203, 215 (1963); Zorach v. Clauson, 343 U.S. 306, 314 (1952); Everson v. Board of Education, 330 U.S. 1, 18 (1947).

${ }^{69}$ ELY, DEMOCRACY AND DisTRUST 100 (1980).

${ }^{70}$ University of California Regents v. Bakke, 438 U.S. 265 (1978).

${ }^{11}$ Fullilove v. Klutznick, 448 U.S. 448 (1980).

${ }^{72}$ An example of such a case is Wisconsin v. Yoder, note 29 supra. The Court there concluded that the state's compulsory-education law restricted the free exercise rights of the Amish and ordered that the Amish be allowed a religious exemption. In so doing the Court consciously overrode the Establishment Clause principle that the government must give equal treatment to religion and nonreligion. $1 d$. at 220-21. See also Kurland, Tbe Supreme Court, Compulsory Education, and the First Amendment's Religion Clauses, 75 W. VA. L. REv. 213, 236-37 (1973). I suggest in Sec. IV that the neutrality principle of the Establishment Clause may be stated in such a way that it is consistent with the outcome in Yoder though not with the results in Tbomas and Sberbert. 
Tbomas $^{73}$ and by Justice Harlan in Sherbert. ${ }^{74}$ I think, however, that by awarding benefits to Thomas, the Court not only undertook a legislative task but also violated the Establishment Clause-just as the State of Indiana would have done had it voluntarily enacted the religious exemption which the Court said was constitutionally required.

If the Establishment Clause in fact states a kind of equality principle, the Rehnquist-Harlan position assumes that it tolerates benign legislative intervention just as the Equal Protection Clause does regarding racial classifications. But the arguments that support affirmative action in the latter case simply do not wash when applied to religion.

One such argument, which goes to the substance of the harm ca, ed by discrimination, maintains that the evil of racial classifications is that they stigmatize the disfavored class. Because that does not occur when whites are disadvantaged vis-à-vis blacks, we need not demand exceptional reasons to uphold benign classifications. ${ }^{75} \mathrm{~A}$ second argument, really an evidentiary presumption, is that we need not be unusually suspicious of classifications that disfavor the political majority because its members are unlikely to hurt themselves without good reason. ${ }^{76} \mathrm{~A}$ third argument, defensive in nature, is that even if we look equally hard at benign and malign discrimination, we can on occasion find compelling enough reasons for approving the former.

One is tempted to leap at the first two as support for Indiana's hypothetical religious exemption. After all, most Hoosiers will feel no psychic or moral affront if Jehovah's Witnesses are given special consideration. And it is hard to believe that a legislature in which the Witnesses are hardly represented at all is gearing up for an offensive on behalf of the Kingdom. But both those suggestions ignore the fact that the exemption carved out by the Court favored

73 101 S. Ct. at 1435.

74374 U.S. at 422.

${ }^{75}$ Bakke, note 70 supra, at 357-58, 374-75 (opinion of Brennan, J.); Dworkin, Wby Bakke Has No Case, NEw YoRK Review of Books 11, 15-16 (November 10, 1977); Greenawalt, Judicial Scrutiny of 'Benign' Racial Preference in Law School Admissions, 75 COLUM. L. REV. 559, 570-71 (1975).

${ }^{76}$ See Ely, Tbe Constitutionality of Reverse Racial Discrimination, 41 U. CHI. L. REv. 723 (1974). That argument is what underlay Justice Brennan's emphasis in Bakke on the fact that "whites as a class [do not] have any of the "traditional indicia of suspectness . . . " Note 70 supra, at 357. 
religions generally. The same would be true of any modification that Indiana might make in its Employment Security Act. That makes the second argument, the evidentiary presumption, untenable: we may not be suspicious of classifications benefiting fringe sects, but the collective forces of religion are another matter. It is a rare legislator who has the temerity to disclaim a belief in God. The general nature of the exemption also undercuts the first argument by making the individual harm more substantive: the Establishment Clause, no less than the Equal Protection Clause, is worried about the psychic and moral affront from discrimination, ${ }^{77}$ and that evil is likelier to ensue from general favoritism of religion than it is from special consideration of a distinct minority like Jehovah's Witnesses. The audience is more adult, but apart from that, the problem is not too different from Engel $v$. Vitale ${ }^{78}$ the Regents' Prayer Case. In each situation, the state purposefully uses its resources in a noncoercive and denominationally neutral fashion to favor its religious

${ }^{77}$ I find it odd that this point has not received more attention than it has. That there is such a stigmatic effect seems to me self-evident. Consider the trial testimony of Edward Schempp, explaining why he did not have his children excused from voluntary school-prayer services: "He said that he thought his children would be 'labeled as "odd balls"' hefore their teachers and classmates every school day; . . . that today the word 'atheism' is often connected with 'atheistic communism,' and had 'very bad' connotations, such as 'un-American' or 'anti-red,' with overtones of possible immorality." Abington School District v. Schempp, note 68 supra, at 203, 208 n.3. See also $i d$. at 290 (Brennan, J., concurring) ("even devout children may . . . continue to participate in exercises distasteful to them because of an understandable reluctance to be stigmatized as atheists or nonconformists"); Illinois ex rel. McCollum v. Board of Education, 333 U.S. 203, 232-33 (1948) (Jackson, J., concurring) ("The complaint is that when others join and he does not, it sets him apart as a dissenter, which is humiliating."). Such an impact makes perfectly understandable what has been seen as a unique standing rule for Establishment Clause cases laid down in Scbempp, note 68 supra, at 224 n.9. See Brown, "Quis Custodiet Ipsos Custodes? - Tbe School-Prayer Cases," 1963 SUP. Cr. REV. 1, 15-31. In fact, the rule is no different from that which we apply in equal protection cases. In either instance, discrimination need not amount to coercion, that is to say, to an interference with freedom, to provide a basis for standing. Suppose, e.g., that instead of a prayer the class chanted "White is right" and blacks were allowed to leave the room. That violates no constitutional fteedom that I know of, but is certainly a denial of equal protection, and a black student would undoubtedly have standing to complain. What is more, in an action for injunctive relief, he would not have to prove harm to himself as a factual element of his case. It is a fact of which a court could take judicial notice. Compare Black, The Lawfulness of the Segregation Decisions, 69 YALE L.J. 421, 426-28 (1960), witb Brown, 1963 SUP. CT. REv. at 30-31.

The psychic and moral affront from discrimination may also help explain the complementary standing rule applied in school aid cases. Flast v. Cohen, 392 U.S. 83 (1968). The problem of state aid to sectarian schools is structurally like the problem of state aid to private segregated schools, and in the latter case no one has doubted the standing of black students even though they were not taxpayers. See Norwood v. Harrison, 340 F. Supp. 1003, 1007 (N.D. Miss. 1972), aff'd, note 6 supra.

78370 U.S. 421 (1962). 
citizens over the nonreligious. In Engel, the state actually conducted a religious exercise, whereas our hypothetical amendment funds the performance of religious obligation. But, as the Court has argued in a related context, the distinction between state conduct and state funding is "a formalistic dichotomy that bears . . little relationship ... to common sense."

The third argument for sustaining benign racial discrimination, defensive in nature, has been to look for compelling state interests that will satisfy even the strictest scrutiny. The striking feature of this approach is that the interests advanced are always in the service of a longer-range equality. The claim is that race-conscious action is necessary to achieve some end that pervasive societal discrimination frustrates, ${ }^{80}$ and that such tactics will be unnecessary in a future, more egalitarian, society. ${ }^{81}$ Neither contention can be made about a religious exemption in Indiana's unemployment scheme. There is simply no such thing as societal discrimination against religion generally, ${ }^{82}$ or even any suggestion in the Court's opinion that it was saving Jehovah's Witnesses from the effects of a more focused and local prejudice. ${ }^{83}$ More important still, the institution of a religious exemption is not aimed at any future goal to make religion, like race, irrelevant to decisions about labor relations. On the contrary, it sets up the pursuit of religious options ${ }^{84}$ as a substantive good

${ }^{79}$ Committee for Public Education and Religious Liberty v. Regan, 444 U.S. 646, 658 (1980).

${ }^{80}$ Thus, Justice Powell in Fullilove argued that the minority business set-aside "serves the compelling governmental interest in eradicating the continuing effects of past discrimination identified by Congress." Note 71 supra, at 496. In Minnick v. California Department of Corrections, $101 \mathrm{~S}$. Ct. 2211 (1981), the department contended that it had a compelling state interest in increasing the number of minority correction officers in order to cope with racial tensions in its prisons. Id. at 2215 \& n.11. Even Justice Potvell's argument in Bakke that the state had a compelling interest in pursuing the academic goal of a racially diverse student body addresses a problem - the homogeneity of medical student bodies-which is the product of past discrimination. Note 70 supra, at 369-73 (opinion of Brennan, J.).

81 Bakke, note 70 supra, at 403 (opinion of Blackmun, J.); Dworkin, note 75 supra, at 11.

82 "We are a religious people whose institutions presuppose a Supreme Being." Zorach v. Clauson, note 68 supra, at 313.

${ }^{83}$ As far as the record shows, Thomas may have been the only Jehovah's Witness with a complaint against the law. Thomas v. Review Board, note 7 supra, at 1128-29. Indeed, there is a fair argument that the effect of the decision in Thomas will be to make employers less willing to hire Jehovah's Wimesses then they were before. $101 \mathrm{~S}$. Ct. at 1432.

84 I say "the pursuit of religious options" rather than "religious liberty" because, as Sec. II makes clear, the latter is not affected by the Indiana Employment Security Act. What the Court's decision does is to make more attractive one option-the religious one-which Thomas was already free to pursue. See also text at notes $100-01$ infra. 
which it will be no less important for the state to promote in the future than it is now. But that is precisely what the Establishment Clause is intended to prevent. ${ }^{85}$

\section{B. PROTECTING FREEDOM AND PROMOTING CHOICES}

The comparison with benign racial discrimination suggests not only that the Court was wrong in Thomas and Sherbert, but that the dissenters in those cases were also wrong to say that the state had a wide zone within which it could act to accommodate religion. A look at an even closer parallel-the companion Free Speech Clause of the First Amendment-provides no better support for the Harlan-Rehnquist proposal. The equal protection theory of those free speech cases discussed in Section II is anchored in a belief that it is possible to reach a satisfactory equilibrium in a free speech market. In part, the principle of governmental neutrality is grounded on the trust that uninhibited discussion of public issues will lead to informed decision making, avoid standardization of ideas, and make government responsive to the will of the people. ${ }^{86}$ In part, it is thought to allow a healthy type of social conflict productive of consensus and stable change.$^{87}$ Debate free from government influence is also crucial if scholarship is to flourish, science to advance, and culture to build. ${ }^{88}$ Each of those objectives can be frustrated, as well, when the government offers or withholds financial inducements as when it engages in outright regulation. I argue in Section II that fiscal manipulation did not interfere with freedom of choice. That is not to say, however, that it does not affect the outcome of choices. If every person has his price, then for a suitable aggregate figure, the government can buy unanimity for any posi-

85 "The 'establishment of religion' clause of the First Amendment means at least this: Neither a state nor the Federal Government ... can pass laws which aid one religion, aid all religions, or prefer one religion over another. ... That Amendment requires the state to be a neutral in its relations with groups of religious believers and nonbelievers. ... ." Everson v. Board of Education, 330 U.S. at 15, 18.

${ }^{86}$ Carey v. Brown, note 2 supra, at 462-63, 466-67; Pickering v. Board of Education, note 55 supra, at 571-72; Cox v. Louisiana, note 57 supra, at 551-52; Baggett v. Bullitt, note 54 supra, at 372 n. 10; Edwards v. South Carolina, note 57 supra, at 237-38; Cramp v. Board of Public Instruction, note 54 supra, at 287-88.

${ }^{87}$ Baggett v. Bullitt, note 54 supra, at 372 n. 10; Edwards v. South Carolina, note 57 supra, at 237-38; Cramp v. Board of Public Instruction, note 54 supra, at 287-88.

${ }^{38}$ Police Dept. of Chicago v. Mosley, note 2 supra, at 95-96; Whitehill v. Elkins, note 54 supra, at 59-60; Keyishian v. Board of Regents, note 54 supra, at 603; Shelton v. Tucker, 364 U.S. at $486-87$. 
tion it favors, regardless of the loss to science, scholarship, culture, or informed and creative political decision-making.

There is, however, somewhat more latitude permitted the government when it enters the market as a participant rather than as a regulator. ${ }^{89}$ That is particularly true when the state's entry into the market is designed to preserve or enhance political expression within a democratic system, though the same may be said of efforts to expand the quality, range, and depth of freedom of expression generally. ${ }^{90}$ To take an example considered in Harris v. McRae ${ }^{91}$ and Maber v. Roe ${ }^{92}$ it is improper for a state to prevent parents from sending their children to private schools, but there is no restriction on the state's ability to favor public education by funding it, ${ }^{93}$ and it would be fatuous to suggest that in designing public school curricula the state could not include civies courses which teach the virtues of democracy and the evils of facism. A similar explanation may be given for the holding in Buckley $v$. Valeo concerning public financing of presidential election campaigns. ${ }^{94}$ The funding provisions sustained there allow the distribution of unequal shares of the Presidential Election Campaign Fund to "major," "minor," and "new" parties. The practical effect of Chapter 95 is that a Republican or a Democratic candidate will receive better than $\$ 20$ million, while a Communist or Nazi party candidate will receive nothing. ${ }^{95}$

${ }^{89}$ There is a curious parallel to this aspect of free speech doctrine in the free trade theory of the Commerce Clause. There, as with speech, discriminatory state regulation must meet exacting state-interest and least-restrictive-alternative requirements. But when the state enters the commercial market as participant rather than as regulator, the Court has been more accommodating. Reeves, Inc. v. Stake, 447 U.S. 429 (1980); Hughes v. Alexandria Scrap Corp. 426 U.S. 794 (J976).

${ }^{90}$ An example of the latter is the legislation creating the Corporation for Public Broadcasting. 47 U.S.C.A. $\$ \$ 396$ et seq. (Supp. 1981).

91448 U.S. at 318.

92432 U.S. at $476-77$.

${ }^{93}$ Norwood v. Harrison, note 6 supra.

94424 U.S. at $94-95$.

${ }^{95}$ Chapter 95 of Title 26 establishes a Presidential Election Campaign Fund, 26 U.S.C. § 9006 , and provides that "major party" candidates in the general election shall be entitled to $\$ 20$ million, adjusted for inflation. See 26 U.S.C. \$ 9004(a)(1). A "major party" is defined as one whose candidate for president in the last election received 25 percent of the popular vote. 26 U.S.C. \$ 9002(6). A "minor party" is one whose candidate received 5 percent of the popular vote in the last election. 26 U.S.C. $\$ 9002(7)$. Minor party candidates are entitled to a fraction of $\$ 20$ million, determined by the ratio of the vote received by the party's candidate in the last election to the average of the major party eandidates. 26 U.S.C. $\$ 9004(a)(2)(A)$. "New parties" include all other politieal parties. Their candidates receive no money before the general election, but if they win 5 percent of the vote they are entitled to payments according to the formula applicable to minor party candidates. 26 U.S.C. § 9004(a)(3). 
The Supreme Court concluded that the scheme enhanced, rather than abridged, freedom of speech and so was consistent with the First Amendment. For one thing, displacing private contributions with public funding ${ }^{96}$ made it more likely that political candidates would be responsive to widely shared, rather than narrow but financially powerful, opinions. ${ }^{97}$ Thus, the Act would counteract private distortions in the free speech market. And in deciding how to divide up the fund, Congress could give more money to candidates who took more popular positions, because that, like free speech itself, tended to promote a democratic consensus. To treat all candidates equally, in contrast, would spawn instability by " "artificially foster[ing] the proliferation of splinter parties." "98

If the theory of such cases is that the demands of government neutrality may yield to the purpose of promoting free speech values, there is an obvious parallel in the current doctrine that the Establishment Clause must yield where necessary to protect free exercise values. As the Court said in Wisconsin v. Yoder ${ }^{99}$

an exception from a general obligation of citizenship on religious grounds may run afoul of the Establishment Clause, but that danger cannot be allowed to prevent any exception no matter how vital it may be to the protection of values promoted by the right of free exercise.

To say that the Court was protecting free exercise values in Thomas and in Sherbert, where there was no restriction of free exercise in the first place, is just loose talk. It is important to distinguish between protecting religious liberty, on the one hand, and promoting religious options, on the other. As I demonstrated in Section II, Yoder

${ }^{96}$ In order to be eligible for funds a major party candidate must certify that he will accept no private contributions except to the extent necessary to make up any deficiency in payments received out of the fund. 26 U.S.C. $\$ 9003(b)(2)$. Minor and new party candidates must accept an expenditure ceiling and limit private contributions to an amount which, when added to public funds, does not exceed that ceiling. 26 U.S.C. $\$ 9003(c)$.

${ }^{97} \mathrm{Id}$. at 91 .

${ }^{98}$ Id. at 98 . A related phenomenon has been the willingness to sustain rules about access to broadcast media over claims of interference with editorial discretion. See, e.g., CBS, Inc. v. FCC, 101 S. Ct. 2813, 2829-30 (1981); Red Lion Broadcasting Co. v. FCC, 395 U.S. 367 (1969). In such cases the government's role is regulatory rather than participatory, though the permissibility of more active intervention is premised on the theory that the airwaves are a "part of the public domain." CBS, Inc. v. FCC, 101 S. Ct. at 2829.

${ }^{99}$ Wisconsin v. Yoder, note 29 supra, at 205, 220-21. See also Sherbert v. Verner, note 25 supra, at 413-17 (Stewart, J., concurring); Everson v. Board of Education, note 68 supra, at 17; Tribe, American Constitutional LaW 833-34 (1978); Kauper, Religion and THE CONSTITUTION 71 (1964). 
was a type 1 case, in which the state compelled the Amish to choose an option (school attendance, contrary to their religious belief) that the state preferred, under threat of fine or imprisonment for noncompliance. ${ }^{100}$ That was a clear interference with religious liberty in the sense that the state dictated the outcome of choice by supplying an undesired motive (fear of sanctions). In contrast, the Indiana Employment Security Act did not supply Thomas with any motive he did not already have for keeping his job. But the result of the Court's decision was to promote the contrary option - the religious one - which Thomas was already free to pursue.

It is on that distinction that the free speech comparison founders. In the realm of expression, the government can not only protect liberty but also promote particular options, such as preference for democracy over fascism. Not so with religion: ${ }^{101}$

"Our constitutional policy . . . does not deny the value or the necessity for religious training, teaching or observance. Rather it secures their free exercise. But to that end it does deny that the

100 Text at note \& note 29 supra.

101 Abington School Dist. v. Schempp, note 68 supra, at 218-19, quoting Everson v. Board of Education, note 68 supra, at 52 (Rutledge, J. dissenting). Note the Court's recognition of the same distinction in Buckley, where it rejected the suggestion that it read an Establishment Clause into the free speech gnarantee. Note 5 supra, at $92-93$ \& n.127.

It may be possible to justify a statutory "religious" exemption if it is drawn in terms broad enough to cover everyone, including atheists and agnostics. Suppose that the law allows unemployment compensation to anyone who sees quitting as a choice for or against religion, so that an atheist whose job required her to assist in the manufacture of sacramental objects would be entitled to collect benefits if she quit. $C f$. Young v. Southwestern Savings and Loan Ass'n, 509 F.2d 140 ( 5 th Cir. 1975). In that instance it makes some sense to argue that the state is not promoting religious options but merely protecting religious liberty (i.e., choices about religion, which might have positive or negative outcomes) against private restrictions. To put it another way, such a law would be not a species of affirmative action but simply another application of the principle of nondiscrimination. That is the aim of $\S 703(\mathrm{a})(1)$ of Title VII of the 1964 Civil Rights Act, 42 U.S.C. $\$ 2000 \mathrm{e}-2(\mathrm{a})(1)$, which provides that

(a) It shall be an unlawful employment practice for an employer-

(1) to ... discriminate against any individual with respect to his compensation, terms, conditions, or privileges of employment, because of such individual's ... religion. ...

The provision apparently extends to atheists, see Young supra; EEOC Dec. 72-1114, 4 F.E.P. Cas. 842 (1972); 110 Cong. Rec. 2607 (1964) (remarks of Rep. Celler), and the Court has been uneasy about finding in the law any duty to favor the religious over the nonreligious. See Trans World Airlines, Inc. v. Hardison, 432 U.S. 63, 85 (1977) ("we will not readily construe the statute to require an employer to discriminate against some employees in order to enable others to observe their Sabbath"). Of course, even if the law I have hypothesized would be constitutional, it does not justify the Court's decision in Tbomas, which says that such a measure is not only permitted but required. 
state can undertake or sustain them in any form or degree. For this reason the sphere of religious activity, as distinguished from the secular intellectual liberties, has been given the two fold protection and, as the state cannot forbid, neither can it perform or aid in performing the religious function. The dual prohibition makes that function altogether private."

\section{A RECONCILIATION OF THE FrEe EXERCISE AND ESTABLISHMENT ClaUSES}

Taken together, Sections II and III yield what seem to be two inconsistent principles about the relation of government and religion. The conclusion of Section III is that the equality principle of the Establishment Clause forbids the government to provide any unequal benefit to religion. On the other hand, the discussion of religious freedom in Section II suggests that a law applying to all equally-like the school attendance law in $Y$ oder - might violate the Free Exercise Clause if it provided an undesired motive to refrain from making a religious choice. Or, to turn it around, under some circumstances the government might be required to give special consideration to religion in order to protect free exercise. The apparent conflict of those two propositions does not affect the resolution of Thomas, where free exercise was not involved, but I should say a few words about the problem to show that I have not based my criticism of the case on contradictory premises about the meaning of religious freedom and equality.

Consistency depends on perspective. If one takes the perspective that the First Amendment requires government to treat people equally in all circumstances irrespective of their religious convictions, the principles in Sections II and III seem to be polar opposites. Such a reading of the religion clauses demands, as Philip Kurland has said, ${ }^{102}$

that government cannot utilize religion as a standard for action or inaction because these clauses prohibit classification in terms of religion either to confer a benefit or to impose a burden.

The free exercise principle of Section II is inconsistent with that view because it sees some purely secular laws (like that in Yoder) as restrictions on freedom and calls in appropriate cases for a religion-

${ }^{102}$ See Kurland, Religion AND the LaW 18 (1962). 
conscious solution. On the other hand, if we say, as Gail Merel recently suggested, that the First Amendment requires government to be neutral with respect to religious choices, the principles in Sections II and III come into line. ${ }^{103}$ What the free exercise principle says about cases like Yoder is that government may not affect the outcome of religious choices by supplying a motive ${ }^{104}$ for refraining from religious action. What the establishment principle says about cases like Thomas is that government may not affect the outcome of religious choices by supplying a motive for engaging in religious action.

The difficulty with Professor Kurland's formulation of the neutrality principle is that, in an effort to reconcile the religion clauses, it substitutes "equality" for "freedom" in the Free Exercise Clause and thereby gives that guarantee a meaning significantly more narrow than the principle stated in Section II. ${ }^{105}$ Laws such as "All children must attend school" that make no classification along religious lines are seen as consistent with free exercise if they impose no special burden on religious objectors. ${ }^{106}$ But when the Constitution uses the words "free," "freedom," and "liberty," what it guarantees is protection for individual choice to do or not to do a particular thing. ${ }^{107}$ For example, a law that said "Everyone must stay home after sundown" would abridge my right to freedom of speech if I would otherwise choose to go to night school, or the theater, or to address a Nazi party rally. It would be no excuse that all people were treated alike. In the same way, requiring universal attendance at school irrespective of religious convictions is a way of treating everyone equally, but it restricts the free exercise of religion because it leaves only a Hobson's choice to those who see school attendance as a religious issue.

The second perspective-government neutrality regarding religious choices-does not completely resolve the tension between the two religion clauses, but it does reduce the area of confiict, and it

${ }^{103}$ Merel, The Protection of Individual Cboice: A Consistent Understanding of Religion under the First Amendment, 45 U. Clil. L. ReV. 805, 810-11 \& nn.36, 37 (1978).

${ }^{104}$ A motive which the individual would not choose. See text at note 33 supra.

${ }^{105}$ Cf. Mercl, note 103 supra, at 807-8.

${ }^{106}$ Kurland, Tbe Supreme Court, Compulsory Education, and the First Amendment's Religion Clauses, 75 W. VA. L. REV. 213 (1973).

${ }^{107}$ See tcxt supra at note \& note 28. 
justifies the theory of free exercise predominance ${ }^{108}$ in cases where they cannot be reconciled. The principle eliminates conflict between free exercise and establishment in public benefits cases (like Thomas and Sberbert) by making clear that freedom is not at stake and by enforcing the proscription against government supplying a motive for engaging in religious action. But it is impossible, if we are to give "free exercise" its full meaning, to blink the difficulty presented by religious exemptions from laws imposing general obligations. Take Wisconsin v. Yoder ${ }^{109}$ and Reynolds $v$. United States ${ }^{110}$ by way of example. To refuse to allow an exemption from a compulsory school-attendance law or an antipolygamy law is to provide the Amish or the Mormons with an undesired motive (fear of fine and imprisonment) to make a choice which violates their religious convictions. But to allow an exemption for those with religious scruples is to provide a motive (an opportunity to skip school, a chance to get married twice) for the nonreligious to get religion. The problem dissolves under current doctrine if the state can prove a compelling interest in uniform enforcement, ${ }^{111}$ but that solution will be rare. A second possibility is to make school attendance voluntary and repeal restrictions on multiple marriages; but to do that for every law to which someone could interpose a religious objection would be monstrously impractical. The best we can hope for, if we are still to run a government, is to minimize the effect on the outcome of

\footnotetext{
${ }^{108}$ See text supra at note \& note 99.

109406 U.S. 205 (1972).

11098 U.S. 145 (1878).

11 The principle that the government may not supply a motive for refraining from religious action is not absolute. What it means is that when the government prevents (see note 28 supra), compels (case 1), forbids, or deters (case 2) a particular religious choice, it must have a compelling reason to justify the restriction on religious freedom. See Yoder, note 29 supra, at 215. For example, a draft with no religious exemption might he justified by military necessity. The received learning has it that the state must also prove its law is the least restrictive alternative. Ibid. Cf. Thomas, $101 \mathrm{~S}$. Ct. at 1432.

How Reynolds would fare when measured against these exacting contemporary standards is not clear. It is possible that the Court would relax the demands made on the state along the lines suggested in Braunfeld v. Brown, note 30 supra, at 599, 603-04: "The freedom to hold religious beliefs and opinions is absolute. . . However, the freedom to act, even when the action is in accord with one's religious convictions, is not totally free from legislative restrictions. ... As pointed out in Reynolds v. United States, . . . legislative power . . may reach people's actions when they are found to be in violation of important social duties or subversive of good order, even when the actions are demanded by one's religion." But the significance of the state's interest in preventing polygamy is cast in some doubt by the Court's recent approval of nontraditional family relationships. See cases cited in Developments in the Law, the constitution and the Family, 93 HARv. L. REv. 1156, 1279 nn. 163-66 (1980).
} 
religious choices by requiring the state to take the approach that has the least influence on religious choices. And that will invariably dictate a preference for protecting free exercise. One reason is that any well-written law imposing a general obligation will attach penalties which make obedience more attractive than violation. It is more unpleasant to go to jail, for example, than to go to school or to avoid multiple marriages. That means that the motive for abandoning religious convictions (fear of imprisonment) which results from uniform enforcement is stronger than the motive for adopting a religious position (dislike of school or monogamy) which results from an exemption. A second reason, contingent though it is, will also often be persuasive. It is undeniable that there is an element of self-interest in complying with most laws (going to school, avoiding polygamy), but there is none in paying a fine or going to jail; and to the degree to which complying with the law is appealing in itself, making a religious exemption will not provide a motive for people to adopt a faith they would not buy for its own merits.

The second perspective is also consistent with those Establishment Clause cases holding that the state can provide benefits to religion provided they are no different from the benefits given to competing nonreligious choices. Providing free bus transportation to parochial schoolchildren does not affect the balance of motives for choosing a religious school if free rides are also given to the public schoolchildren. ${ }^{112}$ Of couse, the cases concerning school aid hold that there is something more at issue than neutrality under the Establishment Clause. But tacking on an entanglement codicil to the general neutrality principle does not affect what I have said about free exercise, so I can safely leave to others the decision whether that is a good idea. ${ }^{113}$

112 See Everson v. Board of Education, note 68 supra, at 18. Cf. Walz v. Tax Commission, note 68 supra, at $664,672-73$; id. at 696-97 (Harlan, J., concurring).

113 For suggestions that the entanglement test has not been a notable success see Choper, The Religion Clauses of the First Amendment: Reconciling the Conflict, 41 U. PITT. L. REV. 673 (1980); Kurland, The Irrelevance of the Constitution: The Religion Clauses of the First Amendment and tbe Supreme Court, 24 Villanova L. REv. 3, 19-20 (1978). 
